\title{
MASONCUS SPIDER: A MINIATURE PREDATOR OF COLLEMBOLA IN HARVESTER ANT COLONIES
}

\author{
By SANFord D. Porter \\ Department of Biological Science \\ Florida State University \\ Tallahassee, Florida 32306
}

Symbionts are common in nests of Pogonomyrmex harvester ants (Lavigne 1969, Hunter and Farrier 1976, MacKay 1981 and 1983, Wray 1938). Over ten species of arthropods were found inhabiting Pogonomyrmex badius (Latreille) nests near Tallahassee, Florida. Springtails were especially common; literally thousands of white entomobryids and isotomids were found running through nest chambers. The entomobryid was Pseudosinella rolfsi Mills, a species often found in ant colonies. The isotomid was an undescribed species in what may be a new genus closely related to Folsomia, Proisotoma and Cryptopygus.

Perhaps the most interesting symbiont was a small undescribed spider of the genus Masoncus Chamberlin (Linyphiidae: Erigoninae). These spiders were about $2 \mathrm{~mm}$ long (Fig. 1). Their legs and cephalothorax were pale orange, while the abdomen was slightly darker and grayish. Immature spiders were pale cream colored with a grayish abdomen. Very little is known about the natural history of Masoncus spiders. According to Millidge (personal comm.), these spiders are taxonomically similar to the genus Tapinocyba.

Masoncus spiders in P. badius nests are apparently predators of the symbiotic Collembola. On several occasions, I actually observed these spiders carrying dead collembolans, although I did not see how they were captured. These spiders can spin silk, but probably do not use webs for prey capture because I have never observed more than a few strands of silk in any nest chamber. Symbiotic Thyreosthenius spiders in Britain also prey on Collembola (Bristowe 1939).

Mites were very abundant and might be a secondary source of food for young spiders. The ceilings and floors of nest chambers were often covered with droves of small mites $(4$ species) slowly "grazing" on the substrate. These mites belonged to the families 


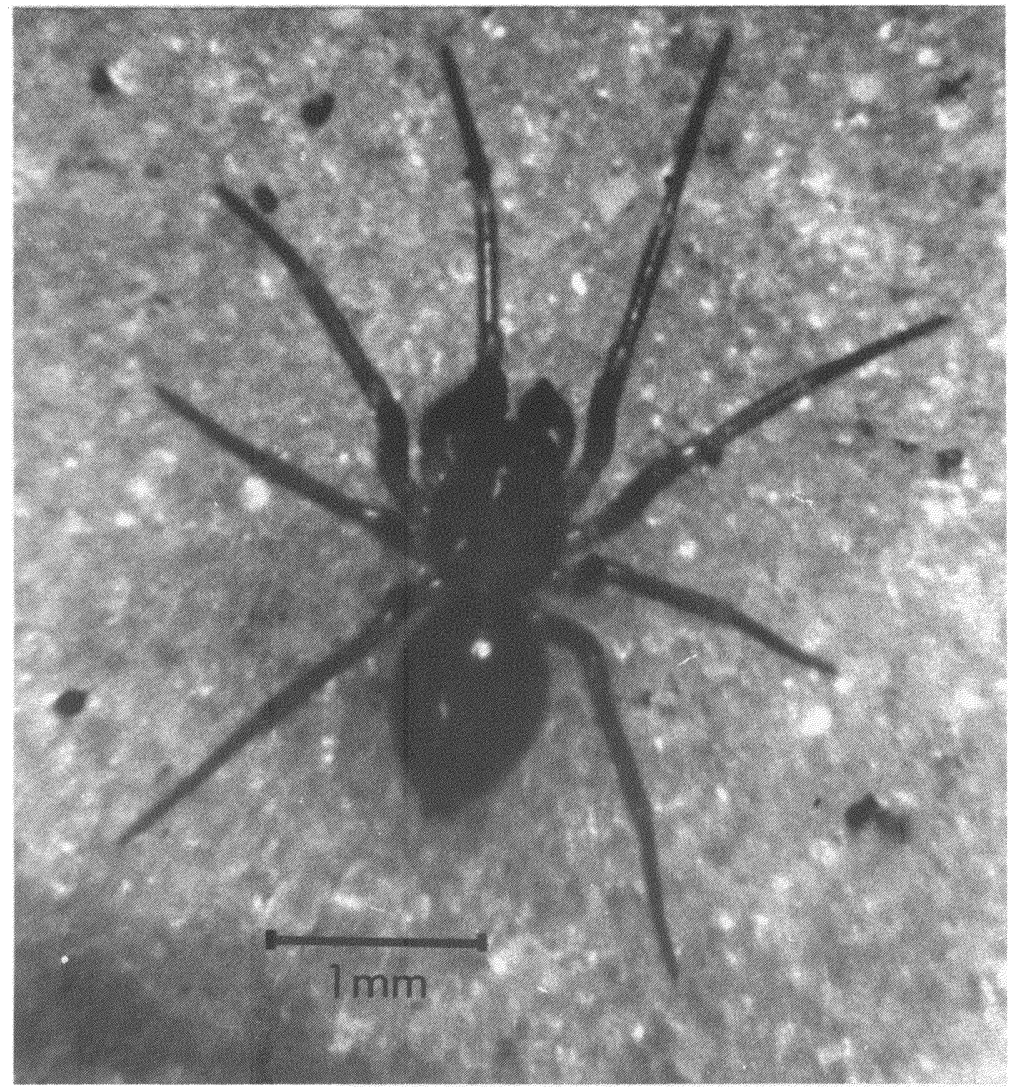

Fig. 1. Male Masoncus spider in harvester ant nest chamber.

Belbidae, Uropodidae, Laelaspidae and Rhodacaridae. Belbids are very small mites common in the soil. Uropodids (Oplitis) are common in moist litter and are also found in ant colonies (Hunter and Farrier 1976) as are laelaspid mites. The laelaspid found in our nests was probably Laelaspis moseri Hunter or Laelaspis mumai Hunter. The rhodacarid belonged to the genus Rhodacarellus, a potentially predatory genus frequently found in deciduous leaf litter. Harvester ant nests also contained a few silverfish (Nicoletiidae), diplurans (Japigidae) and less frequently millipeds and staphylinid beetles. 
I have collected Masoncus spiders from harvester ant nests in three widely separated areas south of Tallahassee, but they are probably much more widespread. Spiders were present in almost all of the harvester ant nests I excavated. Each nest contained from a few to several dozen spiders depending on the size of the colony and how carefully I excavated it. Females outnumbered males by four to one in my collections and were consistently the predominant sex.

Spiders were distributed throughout the colony from the uppermost nest chambers to those more than two meters below the surface. Generally, They seem to prefer deeper $(>60 \mathrm{~cm})$ chambers with fewer ants, but I have also collected them from brood and seed storage chambers. On several occasions, I have even observed spiders briefly running out of the nest entrance: Spiders seem to prefer the ceilings and periphery of the nest chambers, perhaps because this reduces their contact with the ants.

Spiders were present in the ant colonies throughout the year. Both adults and immatures have been collected in the months of March, May, June, July, August, September and November. These spiders have yet to be collected during mid-winter because cold weather severely inhibits my enthusiasm for excavating half frozen ant mounds. Very young spiderlings appear to be most common in the late months of summer. I have collected eggs in July and September but may have overlooked them in other months as well.

White egg sacks are laid in small depressions on the ceilings of nest chambers about one meter below the surface. The egg sack is 3-5 mm across and contains $2-3$ eggs $(x=2.6, n=10)$. The exposed surface of the sack is very smooth and conforms evenly to the contour of the ceiling; if this were not so the ants might destroy the egg sack during chamber maintenance. Spiderlings emerge from the egg sacks after about three weeks $\left(25^{\circ} \mathrm{C}\right)$ through a small hole cut in the surface just off center from the egg cluster.

I am not certain whether these spiders are obligate or facultative guests, but the following evidence indicates that they are more than just casual residents of harvester ant nests: 1) I have never found them associated with other ants (e.g. Solenopsis, Trachymyrmex, Aphenogaster) nor have I chanced across them living independently. 2) Most harvester ant colonies contain at least a few spiders. 3) Spiders are found in harvester ant nests throughout the year. 4) I have observed spiders feeding in the nests. 5) All life stages are 
found in the colonies demonstrating that the spiders successfully reproduce under these conditions. 6) Spiders appear to be capable of emigrating with the ant colony because several spiders were present in a colony which was excavated less than a week after it had emigrated. 7) The best evidence that these spiders are specially adapted for life in harvester ant colonies is that the spiders apparently adopt the odor of their host colony. Spiders and ants from the same colony generally ignore one another; workers occasionally displayed mild aggression but the spider was never captured or injured. However, when I introduced spiders into foreign harvester ant colonies, they were almost without exception attacked and killed within minutes or even seconds. Spiders introduced into laboratory colonies of Trachymyrmex and Aphenogaster ants were similarly attacked and killed.

It would be interesting to know how these spiders disperse among harvester ant colonies, especially how they locate a colony. They are very susceptible to desiccation so it seems unlikely that they would disperse in the daytime. Gaining entrance to a foreign colony would also be a problem since the entrance is sealed at night and guarded by hostile ants in the day.

Many spiders are ant predators (MacKay 1982b, Porter and Eastmond 1982), but relatively few are symbionts (Table 1). Perhaps, this is because spiders have a distinct preference for live prey and are less well adapted to subterranean life than many arthropods. Furthermore, unless a spider actually preys on the ants themselves, colonies must contain rather large and stable communities of symbionts to support a specialized symbiotic predator. The number of symbiotic spider-ant relationships which exist in spite of these seeming impediments (Table 1) is interesting but perhaps not surprising in view of the fact that spiders and ants are among the most abundant of all arthropod groups.

\section{SUMMARY}

An undescribed spider of the genus Masoncus (Linyphiidae: Erigoninae) was commonly found in colonies of the harvester ant Pogonomyrmex badius. This miniature spider is a predator of Collembola and all of its life stages were present in the ant colonies. 
Table 1. Symbiotic spiders and their ant hosts.

\begin{tabular}{|c|c|c|}
\hline Spider & Ant Host & Source \\
\hline $\begin{array}{l}\text { Gnaphosidae } \\
\text { Eilica }\end{array}$ & Camponotus & Noonan 1982 \\
\hline $\begin{array}{l}\text { Clubionidae } \\
\text { Phrurolithus }\end{array}$ & Crematogaster & Emerton 1911 \\
\hline $\begin{array}{l}\text { Salticidae } \\
\text { Cotinusa }\end{array}$ & Tapinoma & Shepard and Gibson 1972 \\
\hline $\begin{array}{l}\text { Agelenidae } \\
\text { Tetrilus }\end{array}$ & Formica & Donisthorpe 1927 \\
\hline $\begin{array}{l}\text { Linyphiidae } \\
\text { Masoncus } \\
\text { Cochlembolus } \\
\text { Evansia } \\
\text { Thyreosthenius } \\
\text { Acartauchenius }\end{array}$ & $\begin{array}{l}\text { Pogonomyrmex } \\
\text { Formica } \\
\text { Formica } \\
\text { Formica } \\
\text { Tetramorium }\end{array}$ & $\begin{array}{l}\text { Porter } \\
\text { Dondale and Redner } 1972 \\
\text { Donisthorpe } 1927 \\
\quad \text { " }\end{array}$ \\
\hline
\end{tabular}

\section{ACKNOWLEDGEMENTS}

I thank A. F. Millidge and W. J. Gertsch for identifying the spiders. Voucher specimens have been deposited with H. W. Levi at the Museum of Comparative Zoology at Harvard University. R. J. Snider kindly identified the springtails and P. Hunter identified the mites.

\section{Literature Cithed}

Bristowe, W. S.

1939. The comity of spiders. Ray Society (London) No. 126, $228 \mathrm{pp}$.

Dondale, C. D. ANd Redner, J. H.

1972. A synonym proposed in Perimones, a synonym rejected in Walckenaera, and a new species described in Cochlembolus (Araneida: Erigonidae). Canadian Entomol. 104: 383-407.

DoNisTHORPE, H. STJ.

1927. Guests of British Ants. London. 244 pp.

EMERTON, J. H.

1911. New spiders from New England. Connecticut Acad. Arts Sci. 16: 383-407.

HuNTER, J. E. AND FARrier, M. H.

1976. Mites of the genus Oplitis Berlese (Acarina: Uropodidae) associated with ants (Hymenoptera: Formicidae) in the southeastern United States; Parts I and II. Acarologia 17: 595-624 and 18: 20-50. 
LAVIGNE, R.

1969. Bionomics and nest structure of Pogonomyrmex occidentalis (Hymenoptera: Formicidae). Ann. Entomol. Soc. Amer. 62: 1166-1175.

Mackay, W. P.

1981. A comparison of the nest phenologies of three species of Pogonomyrmex harvester ants (Hymenoptera: Formicidae). Psyche 88: 25-74.

1982. The effect of predation of western widow spiders (Araneae: Theridiidae) on harvester ants (Hymenoptera: Formicidae). Oecologia (Berl) 53: 406-411.

1983. Beetles associated with the harvester ants, Pogonom!rmex montanus, $P$. subnitidus and P. rugosus (Hymenoptera: Formicidae). Coleopts. Bull. 37: 239-246.

NoOnan, G. R.

1982. Notes on interactions between the spider Eilic a puno (Gnaphosidae) and the ant Camponotus inca in the Peruvian Andes. Biotropica 14: 145-148.

Porter, S. D. and Eastmond, D. A.

1982. Euryopis coki (Theridiidae), a spider that preys on Pogonom!rmex ants. J. Arachnol. 10: 275-277.

Shepard, M. and Gibson, F.

1972. Spider-ant symbiosis: Continusa spp. (Araneida: Salticidae) and Tapinoma melanocephalum (Hymenoptera: Formicidae). Canadian Entomol. 104: $1951-1954$.

WRAY, D. L.

1938. Notes on the southern harvester ant (Pogonomyrmex hadius Latr.) in North Carolina. Ann. Entomol. Soc. Amer. 31: 196-201. 

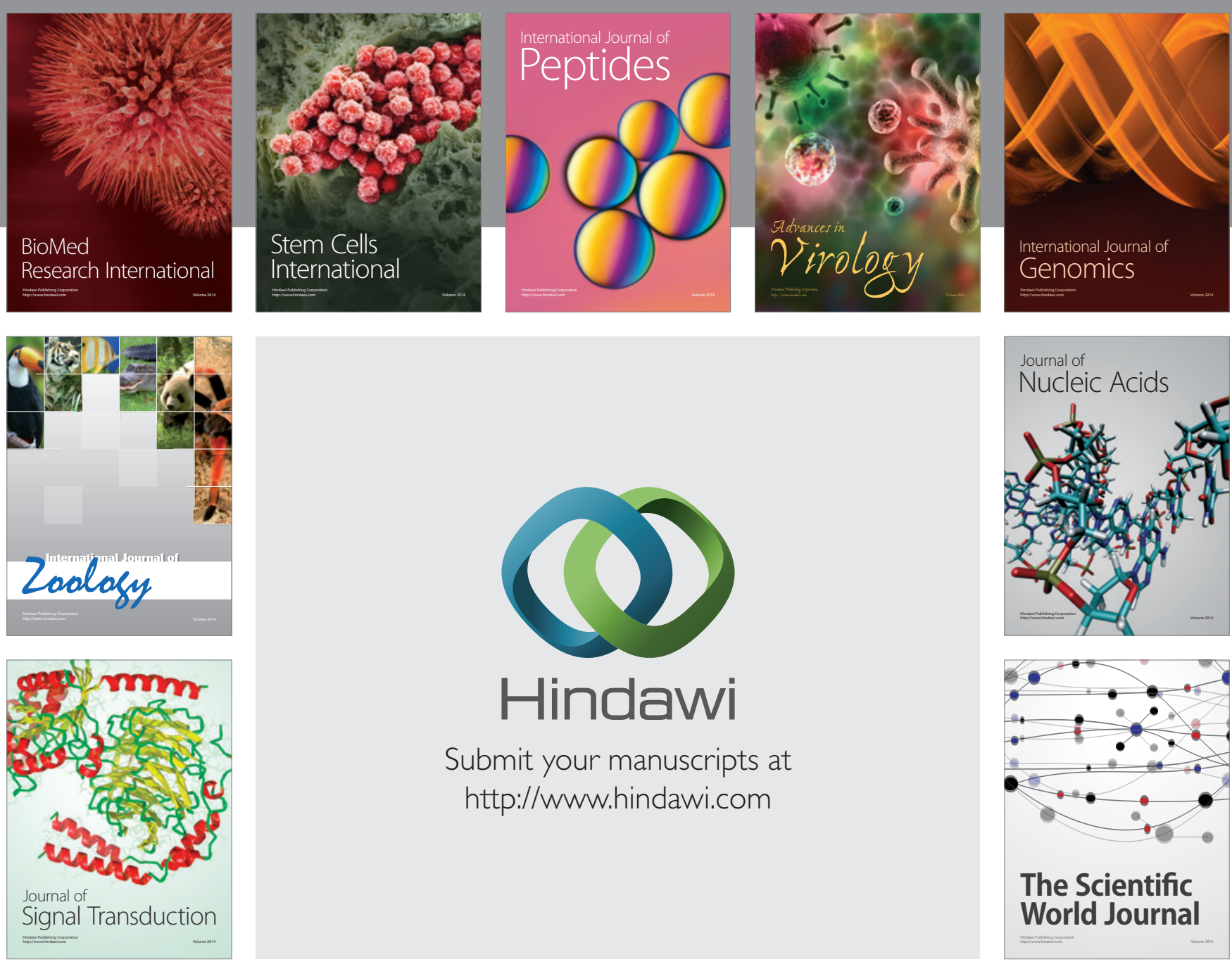

Submit your manuscripts at

http://www.hindawi.com
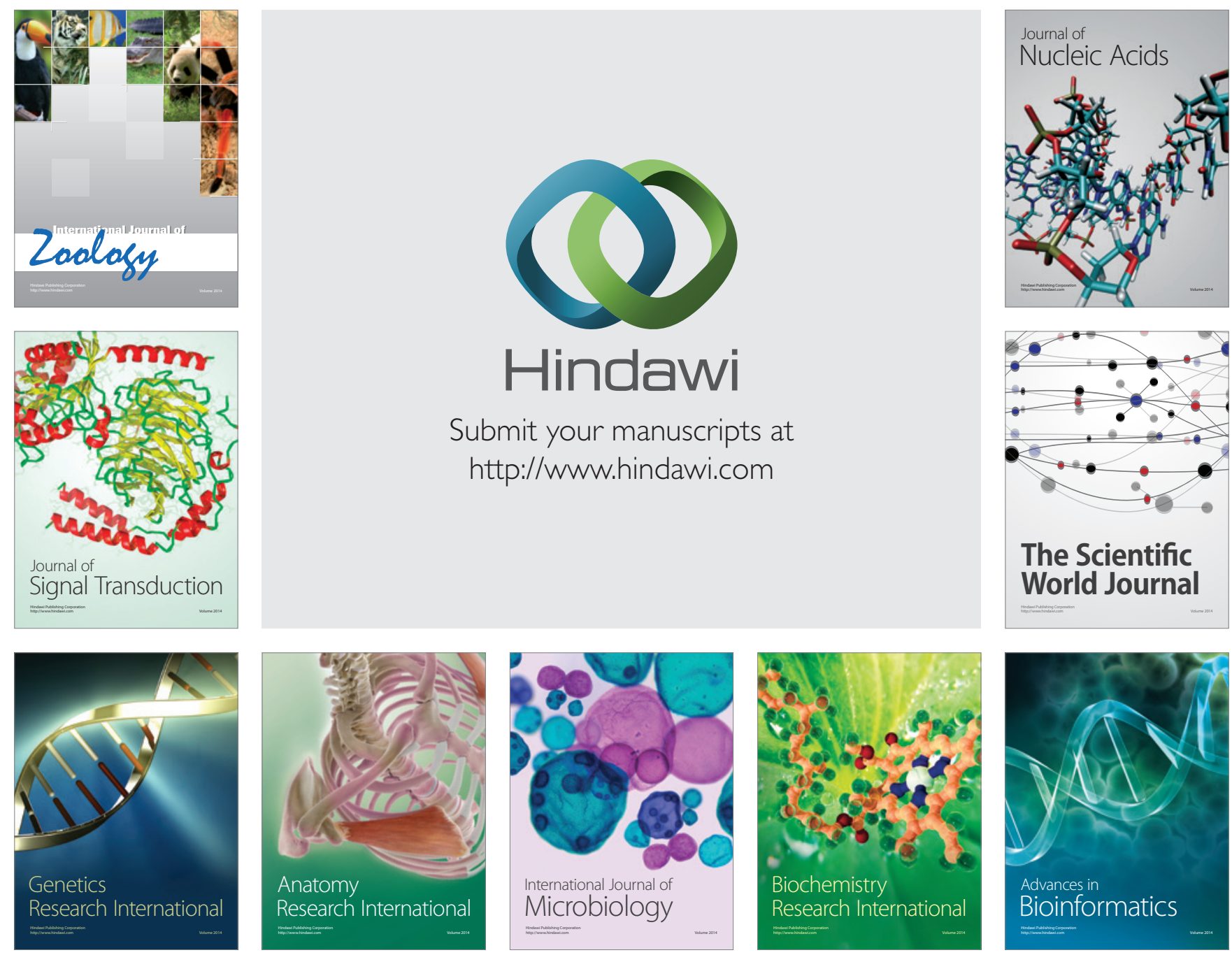

The Scientific World Journal
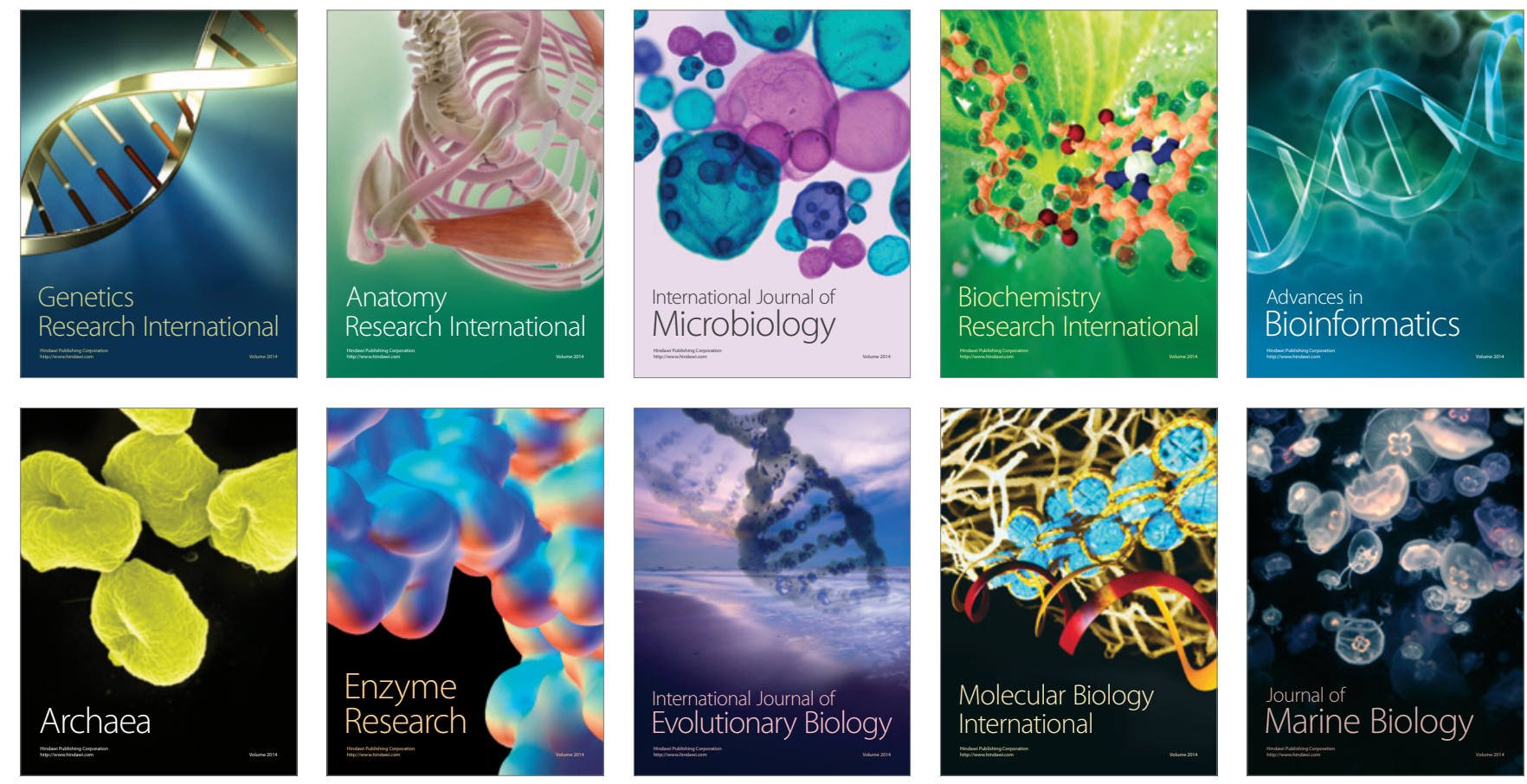